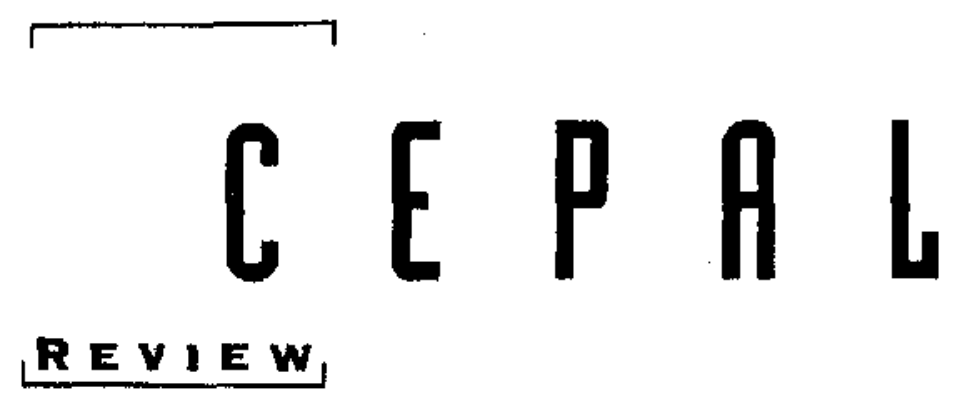

\author{
NUMEEF 65 \\ AUQUST 1998 \\ SANTIAGO, CHILE \\ O S CA ALTIMIA \\ Director of the Review \\ EUGENIO LAHEAA \\ Technical Secretary
}

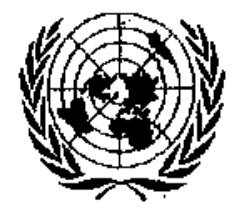


Income distribution, poverty and social expenditure In Latin Amerlca

José Antonio Ocampo

Military expenditure and development in Latin America

Eugenio Lahera and Marcelo Ortuzar

Growth, dlstrlbutive justice and social policy

Andrés Solimano

Equity, forelgn investment and International competitiveness

Adolfo Figueroo

Tensions in Latin American structural adjustment:

allocatlon versus distribution

Daniel M. Schydlowsky

Compethliveness and labour regulations

Luis Beccaria and Pedro Galín

Latin American femilles: convergences and divergences in models and pollcles

Irma Arriagada

Free trade agreements and female labour: the Chilean sltuation

Alicia Frohmann and Pilar Romaguera

Macroeconomic trends in Paraguay from 1989 to 1997:

consumptlon bubble and financial crisis

Stephane Straub

The strategies pursued by Mexican firms in their efforts

to become global players

Alejandra Salas-Porras

Pegulating the private provision of drinking water and sanitation services

Terence R. Lee and Andrei S. Jouraviev

Quallty management promotion to Improve competitiveness

Hessel Schuurman

Recent ECLAC publlcations 


\section{Latin American families: convergences and divergences \\ in models and policies}

\section{Irma Arriegada}

Social Development Division, ECLAC.
The structure, functions and everyday practices of families have changed considerably due to the impact of the demographic, social and economic transformations which have taken place in Latin America. This article begins by describing the complexity and diversity of urban families; on the basis of quantitative data. It then analyses the material conditions through which families have passed and the new approach to these changes. Particular emphasis is placed on such matters as female heads of household and poverty, intra-family violence, and the economic contributions of women and children to the household and to society. Some forms of support are suggested to help family groups exercise their functions, according to the different types and stages of the family life cycle. without projudice to the necessary concem for the basic functions which allow families to maintain themselves over time-access to raterial resources and coverage of basic services- since fulfillment of these minimum functions can help to broaden families' channels of social mobility and build more democratic family structures. An analysis is also made of the role of the family in the construction of solid and integrated societies, even though paradoxically they are assigned functions and called upon to carry out actions which are difficult to comply with in view of the great changes undergone by the family itself, the change in the role of the State in the coverage of certain services, the new roles that family members must play in socicty, and the scanty domestic resources that families currently have. 
I

\section{Introduction}

In its capacity as a means of mediation ${ }^{1}$ between the individual and society and as a link between macroeconomic and microeconomic changes, the family is increasingly considered as the main space for the action of public policies and the area in which they can have the greatest impact. The family is the social ambit in which, in one way or another, individuals take important decisions on their life, their work and other actions affecting their well-being. From the perspective of the State, the family is a mediatory institution in initiatives to promote equity, guarantee basic human rights, and integrate individuals into social and community networks (ECLAC, 1994a). There is a debate from various angles on the role of the family in building solid, integrated societies, but paradoxically no consideration is given to the fact that it is assigned functions and faced with demands which are increasingly difficult to fulfill, both because of the great changes which have taken place in its formation, size and functions, the new roles that its members have to play in society and the scanty internal resources available to families today, and because of the changes in the State's role in providing certain services.

In Latin America, the changes which have taken place in the family in recent decades are widely recognized by governments. The evolution of the institution of the family in the countries of the region displays generally similar tendencies: reduction in the size of the family unit; decline in nuptiality and postponement of the age of marriage; 2 and an increase in early motherhood, common-law manriages, broken marriages,

$\square$ A previous version of this study (Arriagada, 1997) contains more statistical data. The data from household surveys were processed by Ernesto Espindola.

1 The concept of mediation concerns aspects of social reality which act as a "filter" that can heighten, shape or modify the relation between the structural conditioning factors and individual or group actions (Jelin, Llovet and Ramos, 1986; García and De Oliveira, 1994). It is used in the sense of a vertical mediation developed by Berger and Luckmann, that is to say, it refers to the institutions and processes which act as intermediaries between the individual in his personal life and the great social institutions (Berger, 1997).

${ }^{2}$ This is not so in all countries: Cuba registers high nuptiality of very young persons (UNFPANNESCONNACEF, 1997) and a lowering in the age of the first union, as also do Haiti, Jamaica, Panama, Paraguay and Uraguay (CELADE, 1996a). single-parent and single-person bouseholds, and reconstituted families (ECLAC, 1993 and 1994a). In a context of relatively rapid economic and social change, it is noted that not only do the children form families of a different type from those in which they were born but also families within the same generation differ according to their stage in the life-cycle, thus giving rise to a wide range of different family structures (Arriagada, 1995), and this must be taken into account when adopting decisions on public policies.

With the processes of modernization, there have been changes not only in the structure of the family but also in its functions and the way they are carried out. Some functions within the family have lost importance (religious and legal functions and economic production functions), while functions such as early socialization and new functions such as those connected with leisure have come to predominate over others such as social control (Rodriguez, 1995). The functions which symbolically and traditionally define the family are mainly those of reproduction and regulation of sexuality, but it is observed that families are having fewer and fewer children, that there is an increasing number of births out of wedlock or outside the relationship of the couple, and that sexual activity is also carried on ontside the institution of marriage.

Today, the family continues to concentrate the reproductive and affective functions and those of the care and early socialization of children and looking after old people. Functions of a more instrumental type, such as education or economic production for the market, have been transferred to other social levels. With regard to the economic functions, a distinction must be drawn between participation in production activities in the labour market and the economic functions of consumption and reproduction that the family must fulfill through housework. As a result of changes in the structure of production, many functions of the family which were carried out within the home have come to be carried on outside it, thus reducing the amount of time that people spend in it. However, the recurrent economic crises have reversed these trends, especially with regard to employment (home work and own-account work), pre-school education and 
health. Likewise, families in the most under-privileged economic and social circumstances must cover a much broader range of functions (for example, ex- clusive care of small children and old people), which is reflected in an extension of housework, for which women are usually responsible.

\section{II}

\section{Current trends in the urban family}

The demographic, social and economic changes which have taken place in Latin America have transformed the region's family structures. In the last two decades, the region's population has grown by 146 million persons; in addition to a further increase in inequality of income, between 1980 and 1994 the population in a state of poverty increased by 73.4 million persons (ECLAC, 1997); the rate of urbanization increased, and in 1995 the urban population amounted to $74 \%$ of the total; both mortality and the birth rate went down, so that between 1975 and 1995 the expectation of life at birth increased by five years for both sexes; the global fertility rate went down from 4.5 to 3.1 between the same years, and the refined rate of female economic activity ${ }^{3}$ went up between 1980 and 1995 from $27 \%$ to $34 \%$ (CELADE, 1996b). Thus, urbanization, a smaller number of children and an increase in female work outside the home were the most important phenomena in these changes in the family.

Processing of the data from urban household surveys in 12 Latin American countries reveals some relations between the types of families and the incidence of poverty in the home, work and education. For purposes of this comparison, households were classified according to the types of family, constructed on the bases of the family's relationship with the head of household and the stages of the family cycle, defined as a function of the presence and age of children (see Arriagada, 1997). The preparation of this statistical information serves the purposes of comparison and follow-up of trends, but above all of quantitative diagnosis for proper policy design.

The following conclusions may be drawn from the information processed:

\footnotetext{
${ }^{3}$ The refined rate of activity is the quotient of the total number of persons economically active at a given date and the popta. tion of an age considered to be potentially active on the same date; in this case, the population in question was taken as those aged 10 or over.
}

i) In 1994 , between $55 \%$ and $71 \%$ of the fámilies in the countries studied were of the nuclear type. Between 1986 and 1994, the regional averages of the different types of family remained relatively stable, albeit with differences between countries. Households with a female head increased slightly, representing around a quarter of the total number of households

FIOURE I

Latin America (12 countrles): Oistribution of famlly and non-famlly households, by type and by stage in famlly life cycle, 1994

A. Distribution of family and non-family housebolds, by type *

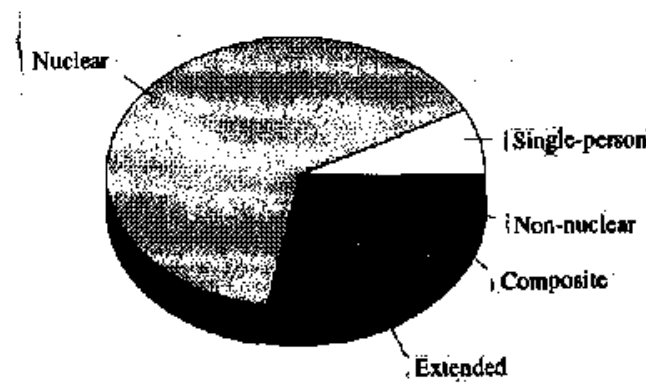

B. Distribution of family households, by stage in family life cycle *

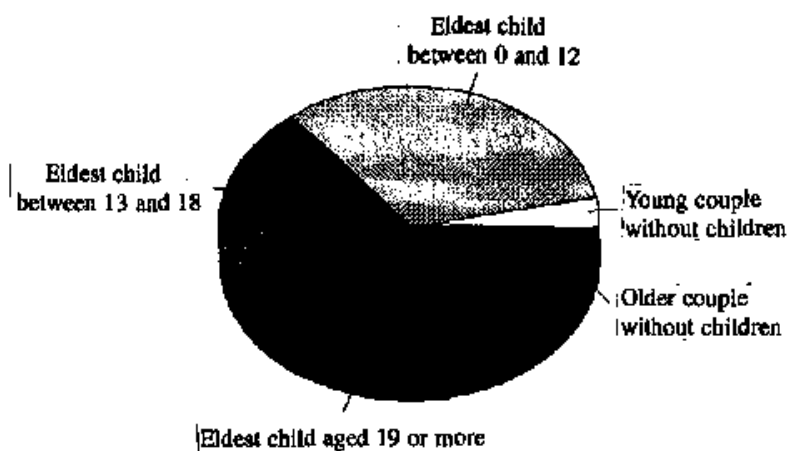

Source: BCLAC, on the basis of special tabulations of household surveys for 12 countries. 
TABLE I

Lotin Amorlca (12 countrles): Types of household and lamlity, by eex of head of household, 1994 (Urban areas)

\begin{tabular}{|c|c|c|c|c|c|c|c|c|c|c|c|}
\hline \multirow[b]{2}{*}{ Country } & \multicolumn{5}{|c|}{ Femalo head of houschold } & \multicolumn{5}{|c|}{ Male head of household b } & \multirow[b]{2}{*}{ Total } \\
\hline & $\begin{array}{l}\text { Single. } \\
\text { person } \\
\text { household }\end{array}$ & $\begin{array}{l}\text { Nuclear } \\
\text { family }\end{array}$ & $\begin{array}{l}\text { Extended } \\
\text { or com- } \\
\text { posite } \\
\text { fannily }\end{array}$ & $\begin{array}{c}\text { Non- } \\
\text { nuclear } \\
\text { household }\end{array}$ & Subtotal & $\begin{array}{l}\text { Single- } \\
\text { person } \\
\text { household }\end{array}$ & $\begin{array}{c}\text { Nuclear } \\
\text { family }\end{array}$ & $\begin{array}{c}\text { Extended } \\
\text { or com- } \\
\text { posite } \\
\text { fanily }\end{array}$ & $\begin{array}{c}\text { Non- } \\
\text { nuclear } \\
\text { household }\end{array}$ & Subtotal & \\
\hline Argentina & 10.4 & 7.2 & 2.7 & 2.3 & 22.6 & 4.9 & 59.4 & 11.0 & 2.2 & 77.5 & 100.0 \\
\hline Bolivia & 2.9 & 8.6 & 4.5 & 1.8 & 17.8 & 4.7 & 62.6 & 12.8 & 2.0 & 82.1 & 100.0 \\
\hline Brazil ${ }^{\circ}$ & 4.3 & 9.2 & 4.7 & 2.4 & 20.6 & 3.6 & 61.7 & 12.5 & 1.6 & 79.4 & 100.0 \\
\hline Chile & 4.5 & 7.6 & 6.1 & 2.5 & 20.7 & 3.5 & 56.5 & 17.6 & 1.7 & 79.3 & 100.0 \\
\hline Colombia & 2.7 & 9.5 & 7.7 & 3.0 & 22.9 & 2.3 & 54.7 & 17.5 & 2.5 & 77.0 & 100.0 \\
\hline Costa Rica & 3.2 & 10.0 & 7.5 & 2.0 & 22.7 & 2.6 & 57.1 & 15.8 & 1.7 & 77.2 & 100.0 \\
\hline Honduras & 1.5 & 8.7 & 10.2 & 3.1 & 23.5 & 1.9 & 49.5 & 23.5 & 1.6 & 76.5 & 100.0 \\
\hline Mexico & 3.0 & 7.4 & 4,4 & 2.0 & 16.8 & 3.0 & 63.4 & 14.5 & 2.3 & 83.2 & 100.0 \\
\hline Panama & 2.7 & 9.5 & 7.8 & 2.6 & 22.6 & 5.5 & 51.2 & 17.6 & 3.2 & 77.5 & 100.0 \\
\hline Paraguay & 3.3 & 7.4 & 7.2 & 3.1 & 21.0 & 4.5 & 47.5 & 25.4 & 1.7 & 79.1 & 100.0 \\
\hline Uruguay & 11.0 & 7.5 & 4.2 & 3.1 & 25.8 & 4.2 & 55.4 & 12.6 & 1.9 & 74.1 & 100.0 \\
\hline Venezucla & 2.0 & 8.6 & 10.4 & 2.3 & 23.3 & 3.5 & 48.4 & 22.7 & 2.1 & 76.7 & 100.0 \\
\hline
\end{tabular}

Sonrce: Special tabulations of bousehold surveys for the respective coumtries.

- The muclear, extended and composite families are single-parent families.

b. The nuclear, extended and composite families include two-parent families without children, two-parent families with children, and single parent families with a male bead of household.

'Data for 1993.

TABLE 2

Latin America (12 countries): Stage in Itfe cycle of Iamllles, ${ }^{2} 1994$ (Urban areas)

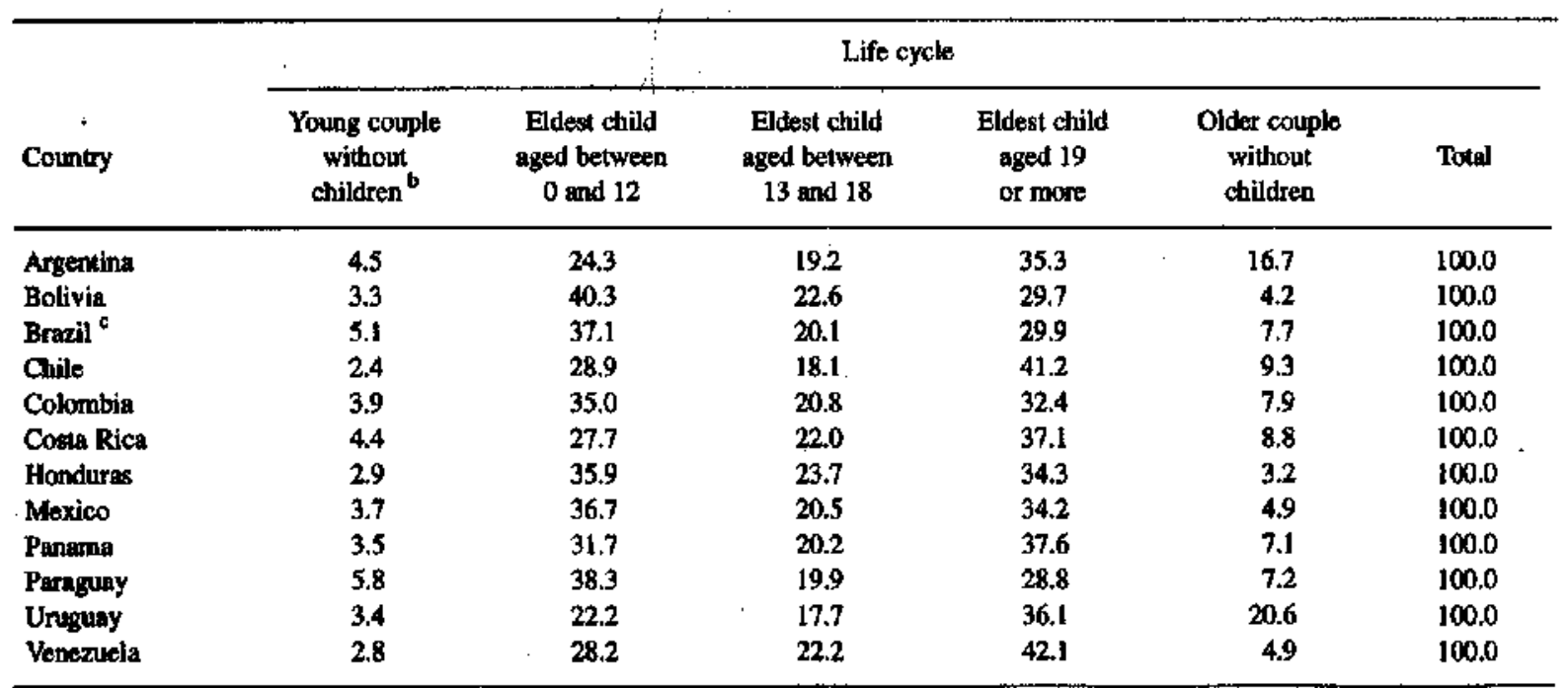

Source: Special tabulations of household surveys for the respective countries.

"Excluding single-person and non-nuctear families.

The female hend of household or spouse is aged 35 or less. In older couples, she is over 35.

¿Data for 1993. 
(between $18 \%$ and $26 \%$ ). Comparable information is not available for countries in the Caribbean and Central America, where there is a high prevalence of households with a woman head (figure 1 and table 1).

ii) Over this same period there was a slight increase in single-person households, partly because of population ageing in the countries at an advanced stage of the demographic transition, while the proportion of extended and composite families remained unchanged.

iii) In terms of the life-cycle (figure 2 and table 2) there were also very considerable changes in the number of families in each stage, due to major demographic changes (particularly the decline in the birth rate in the $1970 \mathrm{~s}$ ). Thus, there was a big increase in families whose oldest child was over 13 and a reduction in those whose eldest children were below that age.

iv) Households with a female head are concentrated in that stage of the life-cycle in which the oldest child is over 18 (between $56 \%$ and $72 \%$ of households with a female head with children), indicating the accumulation of prior breakups of the cousple, without the formation of new unions, together with situations of widowhood. Although marital status is not very well registered in the surveys or is even not included among the questions at all, there is a great variety of situations in the countries with regard to the marital status of female heads of household: the proportion of widows varies from $55.8 \%$ of woman heads of household in Uruguay (the country where the demographic transition is most advanced) to $26 \%$ in Paraguay and Venezuela. In short, there were few variations in the proportions of families by types of household but big changes in terms of the stages in the family life-cycle.
FIGURE 2

Latin America (12 countrles); Evolution of households, by type and by stage in family life cycle, 1986-1984

(Percentages)

A. Evolution of family and non-family houscholds, by type ${ }^{2}$

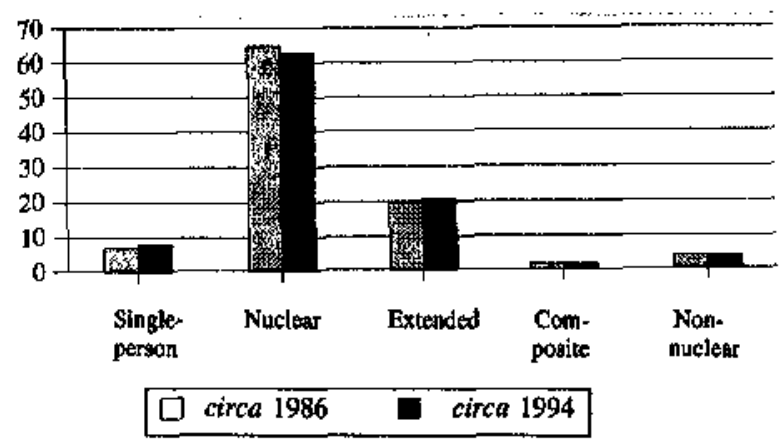

B. Evolution of family households, by stage in family life cycle"

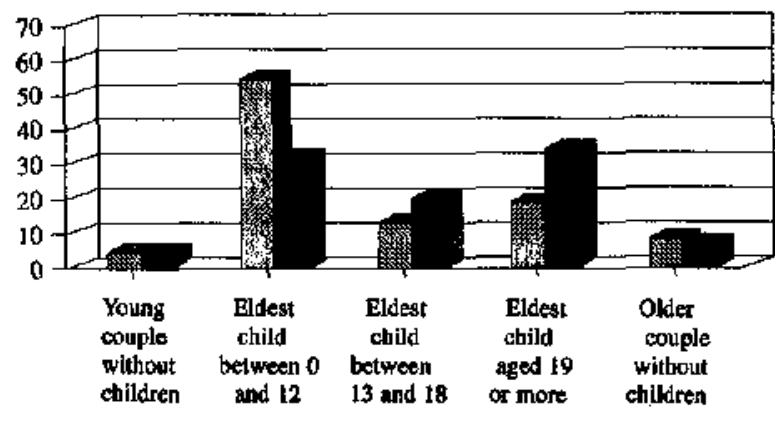

[] circa 1986 cinca 1994

Source: ECLAC, on the basis of special tabulations of household surveys for 12 countries.

`Simple averages for urban areas.

\section{III}

\section{Gender-linked contributions to research}

\section{and policies regarding the family}

The term "gender" has given rise to a great deal of controversy in Latin America, and even researchers themselves have used it indistinctly to refer to female matters, sex, women's movements, feminist movements or women as a whole. ${ }^{4}$ Gender has been de- fined as a social, cultural and historical construct

\footnotetext{
4 For a more theoretical analysis of the evolution of the concept of gender, see Anderson (1996), De Barbieri (1992 and 1996) and Lamas (1996).
} 
asymmetrical valuation of men and women and the power relations established between them (Rico, 1993; Scott, 1990). A valuable epistemological quality of the gender perspective is that it makes it possible to link together structural elements and processes with subjective aspects. It also brings ont the historical dimensions by showing that certain hierarchical constructs of male and female can be modified over time. All in all, gender studies have made it possible to bring out aspects relating to the family which had remained invisible in the past and take a fresh look at housework, inequality within the family, families with a woman head and intra-family violence, thus helping in the design of policies in areas considered to be of a private nature.

Inequality between families has been extensively analysed from the demographic, economic and social perspectives in studies on the formation of families and measurements of access to consumption, poverty, income distribution and coverage of health, education, housing and social security services, etc. The traditional studies on the family carried out from the 1950 s onward were centered on the nuclear farnily. The prevailing assumption in them was that the processes of modernization of society tended to generate a progressive trend towards nuclear families. The organization of this type of family was assumed to be based on a clear differentiation of roles between the sexes: the man should be the breadwinner through his presence in the labour market, while women would mainly take care of the reproductive aspects and the domestic and affective care of men, children and old people (Aguirre and Fassler, 1994). Although these roles were seen as complementary, in reality this division of roles upheld the authority of the male through his role as the breadwinner of the family (Ariza and De Oliveira, 1997), Recent studies from different social, cultural, psychological and gender perspectives have shown that the situation was actually much more complex, not only historically but also with respect to the families of the present.

Traditional neoclassical theory on marriage holds that both members of the couple benefit economically from the increased efficiency achieved through the specialization of the man in production for the market and of the woman in the upbringing of the children (Becker, 1981). Gender-based studies, however, showed up the family as the scene of unequal economic, social, educational and psychological exchanges among members with very different degrees of power through their family relationship, sex and age, and also as the breaking point in the private- public dichotomy. The family relationship, sex, age and skill ${ }^{5}$ of the members of the family are important dimensions which must be taken into account not only with regard to the structure of households but also the bargaining capacity, decision -making and access to and use of material and symbolic resources within the home. The gender bias is seen in access to land and housing ownership and in the implicit and explicit contracts and arrangements on the distribution of resources within the family, which have a major impact on social institutions and the perpetuation of differences (Folbre, 1995).

Inequality within the family is thus a recent subject of research, connected with gender studies and the interest in improving the living conditions of women and children. ${ }^{6}$ The extreme workload of women and the time that they devote to housework, together with child and adolescent labour in times of crisis, brought into question the distribution of power within the home, as well as the distribution of housework arnong the members of the family and the ways of making these chores compatible, especially in poor households, with work outside the home. In the developed countries and the more modern enterprises, the links between work and the family are now recognized from a systemic perspective which considers their interrelations not as contradictory, but as opportunities for generating positive synergies to improve both areas of activity through organizational changes within the enterprise (Bailyn and others, 1996).

This better understanding of the interrelations between the public and private worlds and the different levels of power of the members of the family has been an important contribution by gender studies. This valoric area has given and continues to give rise to major controversies in the developing and developed worlds, because of the difficulty of striking a balance between the privacy and intimacy of persons and the responsibilities of the State for the defence of their rights, which are often very severely violated within the family.

\footnotetext{
${ }^{5}$ It should be noted that the lack of skills or physical or psychological disability of some of the members of the family also places them in a simation of vulnerability.

${ }^{6}$ For an interesting comparative study on intra-family relations in Mexico, Central America and the Caribben, see Ariza and De Oliveira (1997).
} 
The dividing lines between the public and private worlds are flexible and constantly changing, although the historical tendency with regard to the functions and structure of the family points in the direction of the expansion of the public space. The heterogeneity of the social actors who carry out these functions and the functional specialization of institutions is increasingly marked today, in line with the greater complexity of modern societies. It is essential to take these elements into account when considering the construction of the families of the future and especially when formulating policies which will affect them.

In the following sections, on the basis of statistical data, some salient issues in gender studies will be analysed which reflect both the changes in material conditions undergone by families and the new ideas on these changes. Thus, on the one hand the unsatisfied needs of families are highlighted, with special attention to femsle heads of households and their relation with poverty, together with intra-family violence, and on the other emphasis is placed on the economic contributions of women and their children to the household and the contribution made by women's housework to the maintenance of society.

\section{Female heads of household}

Studies and measurements on female heads of household began in the early 1980s, with the pioneering studies of Buvinic and von Helm. They formulated a theoretical statistical measurement of female heads of household, taking into account all the situations where there was no man in the house (mothers who were separated, divorced, widowed, unmarried, etc.) and showed that this was a significant and growing phenomenon in the developing countries which should be taken into account for the formulation of effective policies.

It is claimed that the number of female heads of household is increasing, because of economic trends in general and the poverty which obliges women to seek an income of their own which will give them greater independence, and also because of demographic, social and cultural conditions such as migrations, widowhood, broken mamiages and adolescent fertility (Buvinic, 1991). Although the data are not completely reliable, in view of the differing definitions of female heads of household in censuses and surveys ${ }^{7}$ and the fact that the statistical data are not complete, in Latin America at least one out of every five urban households is headed by a woman. Such families represent between $17 \%$ and $26 \%$ of the total number of households, and in the Caribbean they account for $40 \%$ or more, which, in view of the cultural and statistical definition of "head of household", means that there is no stable couple. ${ }^{8}$ The growth in these figures will probably continue or increase still further if the phenomena causing it also persist (ECLAC, 1994b and 1995).

Female heads of household are usually unmarried or separated mothers, who make up one of the most vulnerable groups of women in the region because they suffer the greatest difficulties in their motherhood. This is particularly so in the case of the group of adolescent mothers, which has increased and combines extreme youth and poverty with a precarious status of head of household (Buvinic and Rao Gupta, 1997). As noted earlier, in countries in an advanced state of the demographic transition, such as Argentina and Uruguay, there is an increasing number of households headed by older women who are widowed or alone, especially in urban aneas, which also needs to be taken into account when preparing social policies.

Indigence is more prevalent in households headed by a woman because such households usually include more dependents, because the wages that women receive in the labour market are lower, and because women simultaneously have to carry out economic and household functions, which limits their choice when seeking employment (which must be compatible with looking after the children).

However, acting as head of household may also be an option for more educated women with greater resources, since the majority of households with a female head are not poor and are those which have increased most in recent decades. Thus, there is a great variety of situations as regards the marital status of heads of household, depending on the level of eco-

\footnotetext{
${ }^{7}$ In household surveys, the head of household is the person recognized as such by the remainder of the nembers of the household. In view of the prevailing cultural patterns, there is a tendency to under-record the number of female heads of household.

${ }^{B}$ It has been considered that the proportion of households headed by women is very high when it represents more than $40 \%$ of the total number of households; high, when the figure is between $30 \%$ and $40 \%$; moderate, between $20 \%$ and $30 \%$, and low, when the proportion is less than $20 \%$ (Ariza and De Oliveira, 1997).
} 
nomic and social development and the demographic transition of the countries, as well as more contingent situations such as migration or armed conflict."

\section{The economic contribution of women and children to the household: virtuous cycle or spurious cycle?}

In the last twenty years there has been an increase in the number of women who live alone or as heads of household with dependents, so that the responsibility for their own survival and that of their family has also increased. Adolescent mothers often do not receive any support from their male partner, and older adults are no longer cared for by their sons: both these tendencies increase the burden on women. Even when women live with a man, the income obtained by the latter is sometimes so inadequate that women and children have to take on the double burden of housework and work outside the home in order to make up the family budget. A study made in Mexico revealed that $17.1 \%$ of households, regardless of the sex of the head of household, reported that family income came exclusively or mainly from women (Rubalcava, 1996), although this is one of the countries which registers the smallest proportion of households with a female head.

A simulation exercise ${ }^{10}$ to find out how much poverty would increase if wives did not contribute their income to the household gave very eloquent results: without that income, in 1994 the number of poor urban households would have increased by between $2 \%$ and $7 \%$, depending on the effective level of poverty and of female labour participation in the countries. In contrast, if all spouses contributed their income to the household, poverty would have gone

9 Separated or divorced female heads of household represent $54 \%$ of the total in Honduras, $43 \%$ in Costa Rica, $42 \%$ in Colombia, $36 \%$ in Bolivia, $24 \%$ in Uruguay, $20 \%$ in Chile and $15 \%$ in Paraguay.

10 The simulation exercise consisted of deducting from the effective income of households the inconse in respect of the work of the wife, calculating the new per capita income of the household, and comparing it with the poverty line, thws updating the percentage of households which would be in a state of poverty if it were not for the contribution of the wife. Secondly, wives who did not declare any income were taken into account, they were imputed the income of spouses who did work, in line with the various categories of poverty, a new per capita income was calculated for the household, and it was compared with the poverty line, thus giving the percentage of households which would be in a state of poverty were it not for the potential contribution of all the spouses.
FIGURE 3

Latln Amerlca (12 countriee, urban areas): Contrlbution by female spouses to family income and fla effecte on the incidence of poverty, 1994 (Percentages)

A. Contribution by female spouses to family income

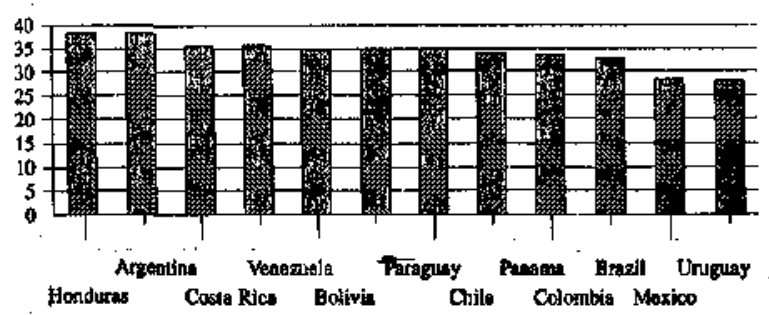

B. Incidence of poverty with and without the contribution of female spouses

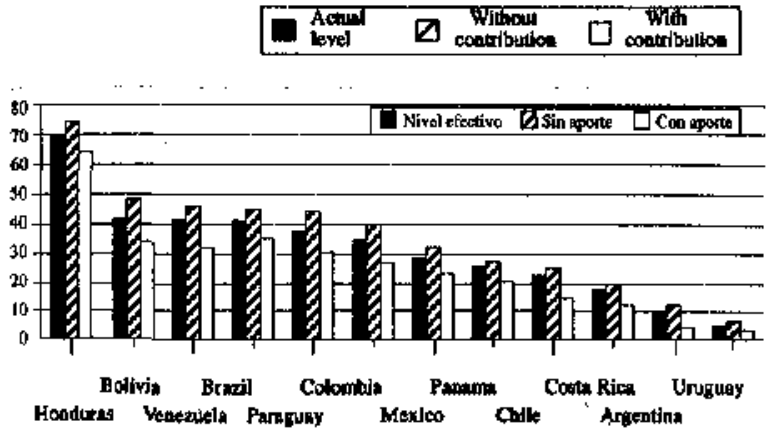

Source: BCLAC, on the basis of special tabulations of household surveys for 12 countries.

down by between $1.4 \%$ and $9 \%$. For the total number of households, wives who were working in 1994 contributed between $28 \%$ and $39 \%$ of total household income (figure 3 ).

The economic contribution made by the work of the children, especially in indigent households, is also very important for the survival of households with female heads. The proportion of young people and childnen in the region who work depends on the countries and age groups, although the available information under-records the number of children and young people who work, because most national legislation prohibits work by persons under 18 . Work by children under that age and even as young as 12 is usually accepted on certain conditions, however (that they go to school and that they only do light work for short periods). Taking the total number of housebolds with children, it was found that when the latter worked they contributed between $16 \%$ and $36 \%$ of household income (Arriagada, 1997). 
The information on the work of women and young people reveals that there are two circles, one virtuous and the other spurious, in the participation of family members in the labour force. The first of these refers to the economic participation of more adult members of the family, which allows the latter to emerge from a state of poverty, while the second refers to the economic participation of children under 18 , which takes them out of the educational system and causes them and their future families to suffer from economic and social deficits which will lead to the reproduction of the inter-generational poventy cycle.

\section{Intra-family violence}

The feminist movement and gender studies also brought into the light of day an old hidden phenomenon: intra-family violence. This is a copybook example of how social movements have redefined some aspects of the family $-a$ private ambit- and turned it into a subject of research and an item on public policy agendas.

The main difficulty in typifying and penalizing intra-family violence is that it is carried out within the household; the aggressor claims that he loves the victim, who depends economically and affectively. on him and fears reprisals from him. There are three types of intra-family violence: physical, psychological and sexual. Some studies also include indirect violence, such as forbidding the spouse to study or work, isolating or locking her up in the house and otherwise restricting her freedom. The special features of this phenomenon make it very difficult to break the cycle of violence: a spiral that begins with a buildup of tensions and hostility, leads to a violent act, continues with the repentance of the aggressor and a promise that it will never happen again (the so-called "honeymoon" stage) but is then followed by a repetition of the same aggressive conduct.

According to world data, one out of every ten women is being or has been subjected to aggressive behaviour by her partier. International statistics indicate that $2 \%$ of the victims of family violence are men, $75 \%$ are women, and in $23 \%$ of cases the violence is mutual (Rico, 1992). This intra-family violence has been registered in all social classes, although the violence tends to be psychological rather than physical in the higher strata. A study carried out in Chile by the National Women's Service (SERNAM) shows that in $60 \%$ of households there is some kind of violence against women, and in one ont of every three households there is psychological violence, while in one out of every four there is physical violence; another study, by UNICEF, revealed that $63 \%$ of all children are victims of physical violence and that the culture of physical punishment is deeply rooted in Chilean households.

Gender studies have shed some light on the phenomenon of intra-family violence. They have pointed out that the family is a paradoxical ambit which fosters not only affection but also violence (Jelin, 1994). They have highlighted women's ignorance of their rights and duties and of the machinery established by the law to apply and guarantee them; the problems that exist at the judicial and police level which hinder the reporting of violations of those rights and the follow-up of the complaints made; and the lack of machinery and institutions to protect the rights of women, young people and children. They have pointed out that women have internalized social values whereby the subordination of women is something "natural". There is thus an acceptance of cultural norms which regulate the life of the couple and the roles of mother and wife; the family and marriage are idealized and made to appear as the only option for women, and social pressures are exerted in different areas of family and neighbourhood life which force women to comply with the dominant cultural mandates (Rico, 1992).

There are also other factors which can be added to these, such as the impunity of criminal acts carried out in private circles; early socialization in a subculture of violence which accepts ill-treatment of women as something natural; the feelings of insecutity and frustration experienced by men when they feel that their authority over women is being threatened, and the precarious conditions in which much of the population live, which can act as triggering factors: overcrowding, poverty, and unemployment, and alcoholism and drug addiction on the part of the aggressor (De Oliveira (ed.), 1996).

Intra-family violence is thus a form of conduct which is learned and can therefore be changed. It is based on unequal relations between men and women and on the fact that masculinity takes the form of the domination of women by men, which can be reflected in physical and psychological violence against those who have less power: women and children. 
Box 1

LATIN AMERICA AND THE CARIBBEAN: LEGISLATION AND STATE ACTION AGAINST INTRA-FAMHLY VIOLENCE,

Country

Argentina

Bahamas

Barbedos

Belize

Bolivia

Brazil

Chile

Colombia

Costa Rica

Cuba

Ecuvador

Ed Salvador

Guatemala

Guyana

Honduras

Jamaica

Mexico
Legislation

Law No. 24,417 ageinst family vioience (1994)

Law on sexual offences and domestic violence (1991)

Law on protection orders against domestic violence (1992)

Law No. 28 on domestic violence

Law No. 1.674 against family or domestic violence (1995)

Legislative Decree No. 107 giving legal force to the Convention to prevent, punish and eliminate violence against women (1995)

Law No. 19325 against intra-family violence (1994)

Law No. 294 on intra-family violence (1996)

Law against domestic violence (1996)

Revision of the Family Code

Law No. 839 on yiolence against women and the family (1995)

Decree-Law No. 902 against intra-family violence (1996)

Law on domestic violence (1994)

Law for the prevention, punishment and elimination of violence against women (1997)

Law on domestic violence (1996)

Law on the prevention of intrafamily violence in the Federal District and assistance to victims (1996)
Examples of Sinte action

Pocventive progranumes, shelters, special police units (Buenos Aires), 24-hour telephone

Shelters, "hol lines", legal support

Special training for police officers, legal support, "hot lines'

Shelters, legal support, training for professional $\mathrm{B}$ and volunters in the health and social sectors and the police

Public Prosecutors' Offices for family affairs, special police department for protection of women and the family, intogral legal services

Special police units to attend to victims of domestic and sexual violence, shelters, Women's Support Centre

Municipal centres for attention to battered women, Press campaigns, research, information centres, special police units, rational training programone for public officials and police officers (intra-family violence will form part of the police training programme)

Special police units for family matters, training workshops on violence against women (CERFAMI, Medellfin)

Special department for wornen's affairs and defence, national plan for dealing with and preventing violence (1996-1998), temporary shelters

Centres for the guidance of women and the family

Press campaign, legal aid, special police units for women and the family

Public Defender of women's human rights

Public Defender of women's rights, in the Office of the Public Prosecutor for Human Rights (Women and Child Unit)

Training courses on domestic violence

Workshops to generate increased awareness of the problem; legal aid

Preventive campaigris in schools on dispule settement; shelters

Centre for dealing with intra-family violence; specialized agencies to deal with sexual offences 
Box 1 (continued)

\begin{tabular}{|c|c|c|}
\hline Country & Legislation & Examples of State action \\
\hline Niearagua & $\begin{array}{l}\text { Law No. } 230 \text { to reform and expand } \\
\text { the penal code to prevent and punish } \\
\text { intra-family violence (1996) }\end{array}$ & $\begin{array}{l}\text { Commission against domestic violence; special police } \\
\text { units }\end{array}$ \\
\hline Panama & $\begin{array}{l}\text { Law No. } 27 \text { defining the offences } \\
\text { of intra-family violence and } \\
\text { ill-treatment of minors (1995) }\end{array}$ & $\begin{array}{l}\text { National commission against intra-family violence ald } \\
\text { ill-trealment; municipal centre }\end{array}$ \\
\hline Paraguay & & $\begin{array}{l}\text { Preventive campaign; special police stations; special public } \\
\text { prosecutors' offices for the family and minors }\end{array}$ \\
\hline Peru & $\begin{array}{l}\text { Law No. } 26260 \text { (1993) amended by } \\
\text { Law No. } 26763 \text { on domestic violence } \\
\text { (1997) }\end{array}$ & Special women's units; shetters; special police procedures \\
\hline Dominican Republic & $\begin{array}{l}\text { Law No. 24-97 defining the offences } \\
\text { of intra-family violence, sexual } \\
\text { harassment and incest (1997) }\end{array}$ & Programme of legal clinics; shelters; "hot lines" \\
\hline $\begin{array}{l}\text { St. Vincent and the } \\
\text { Grenadines }\end{array}$ & Law on domestic violence (1994) & Training programmes \\
\hline Trinidad and Tobago & $\begin{array}{l}\text { Law No. } 10 \text { on domestic violence } \\
\text { (1991) }\end{array}$ & Shelters; "hot lines"; legal aid \\
\hline Uruguay & $\begin{array}{l}\text { Law No. } 16707 \text { (Law on the Security } \\
\text { of the Citizen) introduces into the } \\
\text { penal code article No. } 321 \text { bis } \\
\text { defining and punishing domestic } \\
\text { violence (1995) }\end{array}$ & $\begin{array}{l}\text { Special telephone service; special police units; shelters; } \\
\text { information centres }\end{array}$ \\
\hline Venezuela & $\begin{array}{l}\text { Draft Bill om intra-family violence } \\
\text { and sexual harassment (1993) }\end{array}$ & Legal aid systern; assistance offices; shelters; training \\
\hline \multicolumn{3}{|c|}{$\begin{array}{l}\text { Sounces: Data prepared on the basis of ISIS International, Information and Documentation Programme on Violence against Women, } \\
1996 \text { and 1997; Valdes and Gomariz (eds.), 1995; for the Caribbean: information provided by the BCL.AC Subregjonal } \\
\text { Headquarters for the Caribbean; FEMPRESS, No.177 (July 1996), No. } 187 \text { (May 1997) and No. } 189 \text { (July 1997). }\end{array}$} \\
\hline
\end{tabular}

The acceptance and implementation of genderbased policies runs into serious difficulties connected with resistance to change, with the large number of social and political actors involved, with conflicts of interest, with the diversity of institutions which exists in each country and, in particular, with ideological resistance. In spite of this, in recent years most of the Latin American countries have included punishment for intra-family violence in their legislation, and all of them have ratified the inter-American convention for the prevention, punishment and elimination of violence against women (Belén do Pará, 1994).

National and international legislation with regard to children has a somewhat longer history, as it began in 1959 with the Declaration of the Rights of the
Child and culminated in the International Convention on the Rights of the Child in 1989, which included a set of legally binding commitments conceming the survival of children, their personal and social development, and the protection of their physical, psychom logical and moral integrity. There have also been important legislative advances and State action in this field in the 1990s (box 1).

In most of the countries of the region, State and non-govemmental measures have been taken to help and protect battered children and women, including information, dissemination and preventive campaigns, legal and psychological support, the training of monitors for cases of domestic violence, the establishment of "hot lines" for seeking help by telephone, 
reception centres, etc. An important feature has also been the establishment of institutional machinery for dealing with violence, such as centres for specialized attention and assistance to victims, special police stations for dealing with women and the family, government offices for women's affairs, and the establishment of support networks for women's movements. However, the continuing implementation of State and non-governmental action is constantly threatened by budgetary constraints: in many cases it depends on resources from abroad which, when they run out, also lead to the termination of the programme, while in other cases they depend on the goodwill of the current national, state or municipal governments.

Nevertheless, the end of intra-family violence is a cultural change which may be expected in the long term thanks to changes in the socialization and education of boys and girls and in the values of society, which should lead to greater equality between the sexes and the establishment of more democratic relations within the family.

\section{Housework}

Housework is another of the items of analysis highlighted in gender studies. A major theoretical contribution in this area is the conceptualization of the different types of reproduction: biological, dayto-day and social. All societies make women responsible for the day-to-day reproduction effected through housework, which is carried out in each household in isolation, is not recognized as baving an economic value, and is shared unequally according to the level of development of each country, social class, family life cycle and geographical area. The United Nations Development Programme (UNDP) has calculated that in developing countries $66 \%$ of women's work is outside the system of national accounts, so that no accounts are prepared in respect of it, it is not recognized, and it is not assigned a value (UNDP, 1995).

The traditional family model in the light of which plans are usually prepared is that envisaging a head of household who is the breadwinner, a woman who acts as housewife and carries out the housework, and children who, depending on their age, are in the educational system or the labour market until they form their own family units. We know that this family model does not represent the majority, however. In Chile, for example, this model applies in the case of less than half of the families -only $33 \%$, according to Bravo and Todaro (1995)- since a growing proportion of families have more than one breadwinner, there are others where the only breadwinner is a woman (Valenzuela, 1995), and in the extreme cases of indigent families the children also participate in the labour market.

It would appear that we are currently witnessing a process of change in the relations between the sexes within the family system: family roles are tending to become more flexible and to evolve from a highly segregated model like that which traditionally prevailed towards a more democratic model with shared roles, in which men and women come to various kinds of arrangements for the care of the children and the housework.

The most readily visible phenomenon - which marked the beginning of the break with the traditional model and will continue in the future- has been the massive incorporation of women into the labour market. Paradoxically, so far in the great majority of cases women have not succeeded in breaking with the traditional model, so that they have to carry out a double working day (BCLAC, 1989). Some case studies indicate that men are less reluctant to share in the care and attention of the children than to participate in the housework (Duran and others, 1988; Sharim, 1995), Other studies, carried out in a male population with a high level of education, note that in two-parent families there is a disparity between the symbolic discourse of the men, in which they express their agreement with the change in traditional gender roles, and the practical application of their words, since they do not display any systematic commitment to a real change in the unequal distribution of burdens and privileges in the relations between the sexes (Vivas, 1996). In other groups, a slow and laborious process of negotiation has been begun within the couple to work out a new model of shared responsibilities in the home, but there are few studies which bear witness to these changes and to new trends in the distribution and exercise of power in the family. ${ }^{11}$ An aspect which is highlighted in gender studies is that of the changes which take place in the distribution of tasks in the household according to its stage in the family life-cycle (Reca, 1996), in which the arrival of children is a crucial landmark.

11 A recent case study on family responsibilities may bo found in ECLAC, 1998b. 


\section{IV}

\section{Institutional support for the family:} new public policies for new functions

It is the responsibility of the State and other social bodies and institutions to intervene in the area of the family by defining those who make it up, regulating the relations betwen its members, monitoring its functioning, imposing limits on its members and offering supportive solutions through social policies, legal and juridical mechanisms, and concrete institutions and practices (Jelin, 1994). The neo-liberal model rejecting State intervention, which has been applied in various countries of the region, has led to the deregulation of many economic activities, with increases in poverty and unemployment which have had to be palliated through social measures and regulations by various public bodies (employment programmes, housing subsidies, special benefits for female heads of household, etc.).

In other areas relating to the family, the intervention of the State is sometimes implicit and only becomes visible when people do not comply with the established patterns of behaviour: in Chile, for example, children born in and out of wedlock do not enjoy equal rights, and the responsibilities of the parents and the extended family towards so-called illegitimate children are therefore not recognized.

When the family is considered as a target group for policies -apart from the legal rules regulating it in accordance with national legislation- it is also neces. sary to take into account other dimensions of the family group (ECLAC, 1982):

i) The modes of formation, development and dissolution of the family: age when the couple is formed, formal establishment of unions, number of children, stability of the union, stage in the life-cycle.

ii) The internal relations within it: husband-wife; parents-children, relations between brothers or sisters, relations between the nuclear family and the network of relatives, forms of socialization, distribution of power within the family, communication.

iii) Its external relations as a group and the various circumstances affecting them, such as income, housing, and infrastructure and access to services in the areas of health, education and social security.
As the object of government policies, the approach to the family depends on what it is desired to change or retain in this form of functioning. It is therefore necessary to know what are the prevailing modes of organization of the family and the rationale underlying it (for example, organization/disorganization of households). It is likewise necessary to carefully examine its evolution, that is to say, not only its structure at a given moment, but also the changes in the ways it is formed and in its internal and external relations, in order to obtain guidelines regarding the families of the future.

The experience accumulated in the formulation and execution of policies aimed at certain members of the family -such as the children or female heads of household-highlights the importance of developing systemic approaches for the application of these policies, since if the effects of the changes on the other members of the family are not taken into account the results may be wiped out or may be slower than expected. The challenge is therefore to formulate policies by types of families, as a function of their structure and their stage in the family life-cycle, without losing sight of the special features of each of the family's members or their individual needs.

As already noted, because of the diversity of situations through which families pass, the fact that they are constantly affected by the absence or existence of implicit or explicit policies, and the State's ever-increasing difficulty in providing the population with basic services, policy formulation must be adapted more closely to the specific needs of families, according to criteria of selectivity which take account of the families' structure and their current stage in the life cycle.

It is necessary not only to increase the support that social institutions can give to the family but also to improve the participation of the members of the household in family life, so as to strike a fairer balance between the roles of men and women in social reproduction. In achieving this objective, a central role belongs to the world of work, where the organi- 
Box 2

FORMS OF SUPPORT FOR FAMIYY FUNCTIONS

Family functions

Estabishment of bonds between the couple

Procteation and sexual relations between the couple

Giving children a name and stalus

Basic care of children (and of relatives)

Socialization and education of children (and their parents)

Protection of family members

Providing affective care and recreation for family members

Providing services and resources for family members

Forms of support

Laws and policies

Laws and customs regarding marriage, divorce, and the moles of the spouses

Laws and policies on rights with respect to reproduction, customs reganding family size, and the roles of the spouses

Laws on paternity and adoption

Laws and customs on child care and equality of the sexes

Laws on education, traditions and educational policies

Laws on protection of minors and of battered women; penal legislation on intra-family violence

Customs on family life and democratization of the roles of family members

Rules on everyday life and division of work within the farnily unit
Benefits

Aid for married couples and tax reductions

Marriage allowances, matemity leave, tax reductions and assistino with housing

Allowances paid by the father and the State

Child allowances

Free or subsidized schools; free foodstuffs and school materials

Subsidized housing; legal and psychological support activities

Subsidized sick leave for family members

Allowances and benefits

\section{Services}

Family education; mediation in the event of divorce

Mother and child health centres, midwives, family planning, training in family matters

Legal guidance; adoption services

Education of the parents; day nurseries

Pre-school education, schools, family guidance centres

Child protection services; thorapy; shelters

Family guidance; therapies

Self-help services in the home

Source: United Nations, 1993, p. 21.

zation of work can be redesigned to help both men and women to fulfill their labour and family roles.

The coverage and quality of institutional support systems (such as day nurseries and pre-school education) are not usually sufficient to ensure that special attention is given to those who need it most: the poorest women and those who work outside the home. In Latin America, in 1991 pre-primary attention to children between 0 and 5 years of age only covered less than one-fifth of that age group, and in most cases was concentrated in the private sector and urban areas. Some countries in the region have managed to increase the coverage of pre-school education and others have tried to make it legally compulsory, but in most countries there is still a great deal to be done in this respect.
Different forms of support for the functions of the family have been designed, and each country should adopt them in keeping with its own appraisals of the situation of households and the quality of the services provided, as well as the level of relative importance given to the prevention or correction of problems. By way of example, some possible forms of action in the areas of legislation, benefits and services designed to support some key functions of the family are set forth in box 2 .

Likewise by way of example, the most important functions that should be strengthened and the institutions and services that should take action in this respect are identified for different types of families (box 3) and different stages in the family life cycle (box 4). The types of families selected include, for 


\begin{tabular}{|c|c|c|}
\hline \multicolumn{3}{|c|}{ Box 3} \\
\hline \multicolumn{3}{|c|}{ SUPPORT FOR DIFFERENT TYPES OF FAMILIES: EXAMPLES OF FUNCTIONS AND SERVICES } \\
\hline Types of familtes & Functions to be strengthened & Supporting institulions and services \\
\hline $\begin{array}{l}\text { Nuclear families with a } \\
\text { female head in a situation } \\
\text { of poverty or indigence }\end{array}$ & $\begin{array}{l}\text { Production: Generate opportunities } \\
\text { of employment and incorne for } \\
\text { women } \\
\text { Socializetion: Attention to } \\
\text { pre-school and school children } \\
\text { Provision: Of affective and } \\
\text { recreational care }\end{array}$ & $\begin{array}{l}\text { Special prograntues of access to credit; training and } \\
\text { employment for female heads of household (social } \\
\text { investment funds, etc.) } \\
\text { More flexible working hours } \\
\text { Coverage of basic and pre-school educalion } \\
\text { School meals } \\
\text { Open day care centres to look after children during } \\
\text { working hours } \\
\text { Subsidized transport for minors and school children } \\
\text { Mother and child health services; fartily planning and } \\
\text { guidance services }\end{array}$ \\
\hline $\begin{array}{l}\text { Nuclear families with a } \\
\text { tnale head in a situation } \\
\text { of poverty or indigence }\end{array}$ & $\begin{array}{l}\text { Production: Generate training and } \\
\text { employment opportunities for heads } \\
\text { of household and their spouses } \\
\text { Sacialization: Attention to } \\
\text { pre-school and school children } \\
\text { Distribution of roles within the } \\
\text { family } \\
\text { Demacratization of family life } \\
\text { Protection of women and chitdren }\end{array}$ & $\begin{array}{l}\text { Special training and employment programmes for } \\
\text { persons in a situation of extreme poverty (social } \\
\text { investment funds, etc.) } \\
\text { Coverage of basic and pre-school education } \\
\text { Services for taking carte of battered women and children } \\
\text { Mother and child health services; family planning and } \\
\text { guidance services }\end{array}$ \\
\hline Extended families & $\begin{array}{l}\text { Sacialization } \\
\text { Provision: Of affective and } \\
\text { recreational care for family members } \\
\text { Democratization of family ufe } \\
\text { Distribution of functions within the } \\
\text { home }\end{array}$ & $\begin{array}{l}\text { Services caring for the elderly } \\
\text { Self-help services in the hom } \\
\text { Day care centres for the elderiy } \\
\text { Cultural and commonity recreation centres }\end{array}$ \\
\hline
\end{tabular}

illustrative purposes, those in a situation of poverty or indigence, since they have the most urgent needs, although some of the functions which need to be strengthened for them should also be strengthened for families which are not poor. There can be no doubt that a fundamental requisite for the formation of integrated citizens is that the adult members of the family should have access to employment, since this is a basic condition for the maintenance and survival of the household.

Defining the specific aspects which should be strengthened, according to the type of family and its stage in the life cycle, does not mean that there is no need to worry about the basic requisites that all families need to enjoy in order to maintain themselves over time: access to material resources and adequate coverage of housing, health, education and social security services. The fulfilment of these minimum functions helps to improve the quality of life of families and to broaden their channels of social mobility.
In conclusion, it should be repeated that the study of the family as a system is indispensable if it is desired that social policies should actually reach those who need them, and if such policies are to be effective, their analysis should also include the forms of relations within the household between relatives of different ages and sexes and the possible effects of social policies on all of them.

Certain types of traditional functions of the family -especially early socialization- can be expected to lose prominence as they are shared with other social institutions, but at the same time there will be an increase in the importance of other functions, such as those of providing affection and support, which will become more and more significant for persons in an increasingly demanding, competitive and impersonal environment.

There can be no question about the permanence of the institution of the family, which will continue to exist in the twenty-first century with increasingly 


\section{Box 4}

SUPPORT POR PAMIIIES AT DIFFERENT STAGES IN THEIR LIFE CYCLE: EXAMPLES OP FUNCTIONS AND SERVICES

Stage in life cycle of family Functions to be strengthened

Families at the initial stage

Farnilies at stage I of their life cycle (eldest child under 12)

Families at stage Il of their life cycle

(eldest child aged

between 13 and 18)

Families at stage III of their life cycle

(eldest child aged

19 or more)

Families at the

"empty nest" stage
Formation of family: access to housing Division of work within the home Production: access to ernployment Family education

Sacialization: attention to pre-school and school children

Division of work in the home Reproduction

Affective and recreational care

for family members

Socialization: attention to school children Reproduction

Affective and recreational care

for family members

Care of the elderly

Production

Affective and recreational care

for family members

Cane of the elderly

Improving the quality of life

Care of the elderly

Community participation
Supporting Institutions and services

Family planning services and legal guidance on family matters

Centres providing services for families

Job opportunities and employment centres for young

people

Allowances and training for young unemployed

personis

Subsidies for gaining access to housing

Coverage of pre-school and basic echucation

Mother and child health coverage

Family planning services

Family allowances and pre- and post-natal leave

Legal advice

Services for the protection of battered women and children

Coverage of basic and secondary education

Mother and child bealth coverage

Farnify planning services

Family allowances and pre- and post-natal leave

Legal advice

Services for the proxection of battered women and children

Coverage and subsidies for higher education Employment opportunities for young people Subsidies and training for young unemployed persons Services for the protection of battered women and children

Social security coverage

Old age pensions

Health coverage

Day care centres for the elderly

Cultural and community recreation centres diverse structures and probably with new changes in its functions. It is worth asking ourselves, however -in these modern times in which there is an increasing effort to broaden not only the economic and political options but also those of a social and cultural nature- what tensions and alternatives the family will have to face and in what ways we can strengthen the family's role in society and support family projects of a more democratic nature in which the rights of all the members of the family are respected.

(Original: Spanish) 


\section{Bibliography}

Aguirre, R. and C. Fassler (1994): ¿Qué hombres? ¿Qué mujeres7 ¿Qué familias?, Familias siglo XXI, Ediciones de las Mujeres, No. 20, Santiago, Chile, Integrated Set of Information Systems (ISIS).

Anderson, J. (1992); Intereses o justicia: adónde va la discusion sobre la mujer y el desarrollo, Lima, Ediciones Entre Mujeres.

(1996): Construyendo una perspectiva de analisis de género, Taller latinoamericano de formación de formadores/as en género, Rio de Janeiro, 22-25 October, CEAAL-REPEM,

Ariza, $M$. and $O$. de Oliveira (1997): Formación y dinámica familiar en México, Centroamérica y el Caribe, Ibero-Amerikanisches Archiv, Zeitschrift fitr Soziahwissenschafien und Geschichte, vol. 23, No. 1-2, Berlin, Sonderbnuck.

Arriagada, I. (1995); Familia y delito: los nifíos en la calle, Proposiciones. No. 26. Aproximaciones a la familia, Santiago, Chile, Ediciones Sur.

(1997): Polfticas sociales, familia y trabajo en la América Latina de fin de siglo, "Políticas sociales" series, No. 21, LC/L.1058, Santiago, Chile, Economic Commission for Latin America and the Caribbean (BCLAC), October.

Bailyn, L. and others (1996): Re-linking work and family: a catalyst for organizational change, Ford Foundation, WP 3892-96, April.

Becker, O. (1981): A Treatise on the Family. Enlarged Edition, Cambridge, MA, Harvard University Press.

Berger, P. (1997): La modernización conduce al pluralismo, no a la secularización, El Mercurio, Santiago, Chile, 15 June.

Bravo, R. and R. Todaro (1995): Las familias en Chile: una perspectiva económica de género, Proposiciones. No. 26, Aproximaciones a la familia, Santiago, Chile, Ediciones Sur.

Buvinic, M. (1991): The Vulnerability of Households Headed by Women: Policy Questions and Options for Latin America and the Caribbean, "Mujer y desarrollo" series, No. 8, LC/L.611, Santiago, Chile, ECLAC, Women and Development Unit.

Buvinic, M. and G. Rao Gupta (1997): Woman-headed bouseholds and woman-maintained families: Are they worth targeting to reduce poverty in developing countries?, Economic Development and Cultural Change, vol. 45, No. 2, Washington, D. C., International Center for Research on Women (ICRW).

CELAdE (Latin American Demographic Centre) (1996a): Boletín Demografico, No. 57, Santiago, Chile.

(1996b): Patrones reproductivos, estructura familiar y trabajo femenino en América Latina y el Caribe: resultados de investigaciones, Santiago, Chile.
De Barbieri, T. (1992): Sobre la categoría género. Una introducción teórico-metodológica, in Fin de siglo. Género y cambio civilizatorio, Ediciones de las Mujeres, No. 17, Santiago, Chile, Integrated Set of Information Systems (ISIS).

- (1996): Certezas y malos entendidos sobre la categorfa de género, Estudios básicos de derechos humanos, No. IV, San José, Inter-American Institute of Human Rights (IHR).

De Oliveira, O. (ed.) (1996): Las familias mexicanas, Situación de la mujer en México, No. 6, Beijing, Comité Nacional Coordinador de la IV Conferencia Mundial sobre la Mujer, September.

Duque, I. (1996); Estrategias de prevención en violencia doméstica contra la mujer, paper presented at the Encuentro Intercontinental sobre Violencia Intrafamiliar, Mexico City, ISIS, 28-30 October

Durán, M. A. and others (1988): De puertas adentro, "Esrudios" series, No. 12, Madrid, Ministry of Culture, Instituto de la Mujer.

ECLAC (1983): The family as the immediate social framework of children and women, Ftve Studies on the Situation of Women in Latin America, "Estudios e informes de la CEPAL" series, No. 16, Santiago, Chile.

(1989): Latin America: The Challenge of Socializing the Home Environment, "Mujer y desarrollo" series, No. 2, LClL.514, Santiago, Chile, Women and Development Unit.

(1993): Cambios en el perfil de las fanilias: la experiencia regional, LC/G.1761^P, Santiago, Chile. United Nations publication, Sales No, S.93.I.G.7

- (1994a): Family and Future: A Regional Programme in Latin Anterica and the Caribbean, LC/G.1835-P, Santiago, Chile. United Nations publication, Sales No. E.94.II.G.6

(1994b): Social Panorama of Latin America, 1994, LC/G.1844, Santiago, Chile.

(1995): Social Panorama of Latin America, I995, LC/G.1886-P, Santiago, Chile.

(1997): Social Panorama of Latin America, 1996, LC/G.1946-P, Santiago, Chile.

-1998a): Social Panorama of Latin America, 1997, LC/G.1982-P, Santiago, Chile.

(1998b): Compartir las responsabilidades familiares: una tarea para el desarrollo, Report of the Seventh Session of the Regional Conference on the Integration of Women into the Economic and Social Development of Latin America and the Caribbean, LC/G.2016, Santiago, Chile.

Filgueira, C. (1996): Sobre revoluciones ocultas: la familia en el Uruguay, Montevideo, ECLAC Office in Montevideo. 
Folbre, N. (1995): Engendering economics: New perspectives on women, work and demographic change, Proceedings of the World Bank Annual Bank Conference on Development Economics, vol. 2 , Washington D. C., World Bank.

Garcia, B. and $O$. de Oliveira (1994): Trabajo femenino y vida familiar en México, Mexico City, El Colegio de México.

Jelin, E. (1994): Las familias en América Latina, Fantilias siglo XXI, Ediciones de las Mujeres, No. 20, Santiago, Chile, ISIS.

Jelin, E., J. J. Llovet and S. Ramos (1986): Un estilo de trabajo: la investigación microsocial, in R. Conona and others, Problemas metodologicos en la investigación sociodemográfica, Mexico City, El Colegio de México, Programme of Social Research on Population in Latin America (PISPAL).

Lamas, M. (1996): Usos, dificultades y posibilidades de la categorfa de género, in M. Lamas (ed.), El género: Ja construcción cultural de la diferencia sexual, Mexico City, National Autonomous University of Mexico (UNAM), Programa Universitario de Estudios de Gínero (PUEG).

Ramírez, V. (1995): Cambios en la familia y en los roles de la mujer, Serie E-CELADE, No. 44, Santiago, Chile, Latin American Demographic Centre (CELADE).

Reca, L (1996): Familia y trabajo : una tensión no resuelta, in M. E. Valenzuela (ed.), Igualdad de oportunidades para la mujer y el trabajo, Santiago, Chile, National Women's Service (SERNAM).

Rico, N. (1992a): Domestic Violence Against Women in Latin America and the Caribbean: Proposals for Discussion, "Mujer y desarrollo" series, No. 10 , LC/L.690, Santiago, Chile, ECLAC, Women and Development Unit.

-(1992b): Development and Gender Equity: An Uncompleted Task, "Mujer y desarrollo" series, No. 13, LC/L.767, Santiago, Chile, ECLAC, Women and Development Unit.

(1997): Gender-Based Violence; A Human Rights Issue, "Mujer y desarrollo" series, No. 16, LC/L.957, Santiago, Chile, BCLAC, Women and Development Unit.

Rodríguez, J. (1995): Funciones de la familia, La familia en el umbral del siglo $X X I$, Revista ICADE (Review of the Faculties of Law and Economic and Business Sciences and the University Institute of Business Administration), Madrid, Spain.

Rubalcava, R. M. (1996): Hogares con primacia de ingreso femenino, Hogares, familias: desigualdad, conflicto, redes solidarias y parentales, Mexico City, Mexican Demographic Society (SOMEDE).

Salinas, C. (1994); La vida privada, conquista modema, Familias siglo XXX, Ediciones de las Mujeres, No. 20, Santiago, Chile, ISIS.

Sharim, D. (1995): Responsabilidades familiares compartidas: sistematización $y$ análisis, Documentos de trabajo, No. 41, Santiago, Chile, National Women's Service (SERNAM), Departamento de Estudios Área Familia.

Scott, J. (1990): El género: una categoría útil para el analisis histórica, in J. Amelang and M. Nash, Historia y genero: las mujeres de la Europa moderna y contemporínea, Valencia, Spain, Edicions Alfons el Magnanin, Institucio Valenciana d'Estudis i Investigacion.

UNDP (United Nations Development Programme) (1995): Human Development Report 1995.

UNFPA (United Nations Population Fund)/UNESCO (United Nations Educational, Scientific and Cultural Organization)/UNICEF (United Nations Children's Fund) (1997): Memorias del II Encuentro Internacional sobre Familias, La Habana, Centro de Investigaciones Psicológicas y Sociologicas Familia y Desarrollo, Departamento de Estudios sobre Familia.

United Nations (1993): Guide for a National Action Programme on the International Year of the Family, Washington, D. C.

Valdés, T. and E. Gomariz (eds.) (1995): Mujeres latinoamericanas en cifras. Tomo comparativo, Santiago, Chile, Instituto de la Mujer, Latin American Faculty of Social Sciences (FLACSO)

Valenzuela, M. E. (1995): Hogares con jefatura femenina: una realidad invisible, Proposiciones, No. 26, Aproximaciones a la familia, Santiago, Chile, Ediciones Sur.

Vivas, M. W. (1996): Vida domestica y masculinidad, Hogares, familias: desigualdad, conflicto, redes solidarias y parentales, Mexico City, Mexican Demographic Society (SOMEDE). 